"Neo-liberalization: the impact of Chinese exports on South Africa's sociopolitical economy"

\author{
Samuel Augustine Umezurike \\ AUTHORS \\ Chux Gervase Iwu (D https://orcid.org/0000-0002-6290-9864 \\ Lawrence Ogechukwu Obokoh \\ Chinelo Augustine Umezurike
}

Samuel Augustine Umezurike, Chux Gervase Iwu, Lawrence Ogechukwu

ARTICLE INFO

Obokoh and Chinelo Augustine Umezurike (2017). Neo-liberalization: the impact of Chinese exports on South Africa's sociopolitical economy. Problems and

Perspectives in Management, 15(1), 124-131. doi:10.21511/ppm.15(1).2017.13

DOI

http://dx.doi.org/10.21511/ppm.15(1).2017.13

RELEASED ON

Wednesday, 29 March 2017

\title{
(cc) EY-NC
}

LICENSE This work is licensed under a Creative Commons Attribution-NonCommercial 4.0 International License

JOURNAL "Problems and Perspectives in Management"

ISSN PRINT 1727-7051

ISSN ONLINE

$1810-5467$

PUBLISHER

LLC "Consulting Publishing Company "Business Perspectives"

FOUNDER

LLC "Consulting Publishing Company "Business Perspectives"

NUMBER OF REFERENCES

20

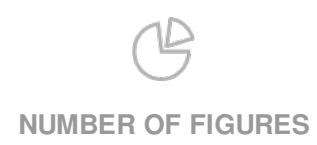

2
NUMBER OF TABLES

2

(C) The author(s) 2022. This publication is an open access article. 
Samuel Augustine Umezurike (South Africa), Chux Gervase Iwu (South Africa), Lawrence Ogechukwu Obokoh (South Africa), Chinelo Augustine Umezurike (South Africa)

\title{
Neo-liberalization: the impact of Chinese exports on South Africa's sociopolitical economy
}

\begin{abstract}
On gaining independence, one of the first steps it took was to open its doors to various socio-economic dynamics. It is fair to say, therefore, that South Africa's neo-liberal approach was necessitated by the nation's desire to diversify its economy in multiple sectors and, therefore, permit foreign direct investment into the country. To most researchers, this has resulted in near deindustrialization leading to gross job losses and reduced standards of living. Essentially, this paper, relying on realist theory, delves into one of the issues, i.e., the demise of the manufacturing sector in South Africa to deliver the poignant explanation pertaining to South Africa's sociopolitical economy. The authors find that the presence of China's finished products in South Africa's market has emboldened and continues to debilitate its manufacturing industry. A major concern is that South Africa's attempts to soften this effect on its manufacturing sector through its protectionist policy - precisely the application of the quota system on imported goods - will not go too far considering the limitations placed on South Africa by virtue of its membership in organizations such as WTO and BRICS.
\end{abstract}

Keywords: China-SA relations, realist theory, BRICS, neo-liberal policies.

JEL Classifications: L6, Z13, Z14.

\section{Introduction}

Neo-liberalization in South Africa's socio-political economy is a child of necessity; essentially owing to the government's intention to diversify the economy in multiple sectors and allowing foreign direct investment into and out of the country. Basically, the neo-liberal movement was a strategy aimed at facilitating transformation and reconstruction of the country since the demise of apartheid (see Sidiropoulos \& Hughes, 2004; Fourie, 2013). Andreasson $(2010,2011)$ also views South Africa's neo-liberal strategy as an opportunity for South Africa to tackle some of the core problems that have paralyzed many sectors of the economy.

In general, concerns have been raised regarding the slow pace of growth and/or lack of dynamism in the entire manufacturing sector of South Africa since the end of apartheid leading many to suggest that neoliberal policy has actually not brought the expected positive changes in the socio-political economy including trade and commerce. To a large extent, fingers point at Chinese import of finished products into South African market as a major cause of near deindustriali-

(C) Samuel Augustine Umezurike, Chux Gervase Iwu, Lawrence Ogechukwu Obokoh, Chinelo Augustine Umezurike, 2017.

Samuel Augustine Umezurike, Dr., Department of Public Administration, Faculty of Commerce, Administration and Law, University of Zululand, South Africa.

Chux Gervase Iwu, Professor, Department of Entrepreneurship and Business Management, Faculty of Business and Management Sciences, Cape Peninsula University of Technology, South Africa.

Lawrence Ogechukwu Obokoh, Professor, Department of Cost and Management Accounting, Faculty of Business and Management Sciences, Cape Peninsula University of Technology, South Africa.

Chinelo Augustine Umezurike, Honours, Department of Economics, Faculty of Commerce, Administration, and Law University of Zululand, South Africa.

This is an Open Access article, distributed under the terms of the Creative Commons Attribution-NonCommercial 4.0 International license, which permits re-use, distribution, and reproduction, provided the materials aren't used for commercial purposes and the original work is properly cited. zation in the manufacturing sector, especially textile and clothing (Edwards \& Jenkins, 2015). This has been used to explain the high level of unemployment and poverty in the country (Rodrik, 2008). Other weaknesses in South Africa's neo-liberalization policy include the structural issues in its economy such as lack of innovation, expensive cost of labor, strict labor laws, lack of skills and development in technology, electricity load shedding, and labor unrest. Meanwhile, productive economies of Europe, USA and Japan have moved up the ladder from the production of tangible goods to producing services. As a result, these economies are no longer competitive particularly in laborintensive manufacturing industry when compared with more competitive China (see Bernard, Jensen, \& Schott, 2006). Nevertheless, with Chinese population, which has given it advantage of cheap labor added to its productive labor-intensive manufacturing sector for decades, the result is that opportunity has been created for domination of Chinese goods in South Africa's market. Thus, Chinese imports to South Africa are ever on the increase since the liberalization of the South African economy and this has had an adverse effect on South Africa's socio-political economy in several directions (Edwards \& Jenkins, 2015).

The worrisome angle of the South African and Chinese trade relations at the wave of global neoliberalization and globalization remains the unfortunate creation of unfair international division of labor. In this regard, South Africa's export to China has steadily remained mostly primary goods, while China on the other hand, has remained the major exporter of manufactured goods into South Africa. The core argument has been that it is not only unfair and unequal relations, but that it is not a sustainable relationship. In fact, the President of South Africa reportedly argued at a Forum on China-Africa Cooperation (FOCAC) in Beijing in 2012 that South Africa's supply of primary goods for China's manufacturing industries plagued 
the nation (see Edwards \& Jenkins, 2015) prompting several analysts to suggest that South Africa's near deindustrialization was a result of this unequal relationship. Interestingly, South Africa has not been able to adjust the trend in its relations with China, for example, in textile and clothing industry. Thus, the economic and political diplomacy between China and South Africa has largely become a replica of AfricaEurope unequal trade relations.

\section{Methodology}

Our view is that despite the structural difficulties that Chinese exports of manufactured commodities into South Africa have created in South Africa's sociopolitical economy, there is still a contextual gap in literature in an attempt to analyze the effects of Chinese export of manufactured products into South African market. Most studies in this area have used quantitative, qualitative and mixed methods of research to examine South Africa's trade relations with China, yet, the contextual treatment of the issues have remained scanty (see Fedderke, 2006; Edwards, Naughtin \& Rankin, 2011). This paper seeks to contribute in bridging the gap through a qualitative review using realist theory to examine the impact of trade relations between South Africa and China on the former's manufacturing industry. This is against the backdrop of the failed attempts by previous researchers such as Edwards and Rankin (2012), Edwards and Jenkins (2015), Pigato and Tang (2015) to utilize realism theory to address the necessity of such a relationship on the basis of South Africa's neo-liberal position at the end of apartheid. The paper, however, relies on documentary analysis to argue that Chinese activities in South African market have beleaguered South African manufacturing companies to the extent that the sector is facing deindustrialization. The documentary analysis method of research allows researchers to make sense of already existing written documents within the public and private domain (Payne \& Payne, 2004; Mogalakwe, 2006). The method gives the researchers the opportunity to choose the written documents that are relevant to the study on the basis of their significance to the subject being investigated. Dey (2005, p. 105) affirms that 'in documentary analysis method of research, the standard for determining relevant written documents for use, or for focusing on particular extracts, should be reflective of the subject which the study seeks evidence for.

\section{Theoretical context}

The following sections provide theoretical context to the discourse. For instance, the next section explains the theory of realism in relation to South Africa since 1990s. This will be followed by an overview of South Africa and Chinese bilateral trade, where we draw from South Africa's trade relations with China since South Africa's neo-liberal reform from 1994 to 2016. Analysis of socio-economic impact of Chinese exports on South African manufacturing sector discusses Chinese capture of sales of manufactured products in South Africa's market through its excessive export into South Africa. This is followed by the analysis of impact of Chinese exports into South Africa on the social life of citizens. The section examines the structural problems, which the excessive export of Chinese manufactured goods into South Africa has created in South African society. Finally, we drew conclusions.

\section{Literature review}

3.1. Understanding the theory of realism in South African context. In the opinion of Amin et al (2011), in the $15^{\text {th }}$ and $16^{\text {th }}$ century, realism theory was the most valid theory for analyzing events in both national and international politics. The advocates of the theory of realism are of the view that human beings are selfish and are continuously striving for advancement of their ego while in active competition with one another (Mills, 2004). As a realist state, South Africa believes that for national pride and safety, it is motivated to acquire more power. Thus, the interest of state is the acquisition of power to guarantee influence in the world of lawlessness (Rose, 1998; Mills, 2004). The main objective of the proponents of realist theory is to advance the development and use of national power. Hence, maintenance of balance of power becomes important. The democratic South Africa rejoined global affairs at the time Union of Soviet Socialist Republics (USSR) had disintegrated setting the stage for new unipolar world order or world hegemony, as many have argued. Thus, South African interest was not on military strength, but reintegrating into the global economy in advantageous position. The core argument of realist theories remains that state is the most important international player, while it relies on power acquisition as the most important means of exercising influence (Rose, 1998; Mills, 2004; Keaney, 2006). The simple idea is that state's command of respect depends on its strength, because the ability to accumulate power exemplifies the influence and respect that are accorded to any nation. For policy makers of South Africa, liberalization of its economy became the best option to outwit other developing economies, as this would provide its home grown compradors the necessary opportunity to play bigger roles in the international political economy. At this stage, South Africa underestimated the possible effect or the backlash on the home manufacturing industries if it fully liberalized trade with other more competitive economies such as China, India and Brazil.

Mills (2004) argues that realist theory contradicts the idealist theory, because the latter assumes that the world is dependent on morality, people's interest and popular public interest as the modus operandi. In the view of realists, the only basis for securing national interest is to ensure that power is within the reach of the state. Power could be seen from two different angles: hard power (military) or soft power (economic 
power or diplomatic power). South Africa's plan was to use the economic leverage it had achieved from neo-liberalization to become a power broker among middle power countries and to play major roles in South-South relations and North-South relations.

Military power means nations' strength in the use of force and armory. A replica of the use of military power could be seen from the USA's intervention during the Second World War, in Iraq in 1990s and 2003, in Afghanistan and in Libya. Economic power could be seen from USA's capital outflow and inflow, which it uses to influence events at the global level, while diplomatic power implies the use of policies and persuasion to deliver national goals and objectives. Therefore, it could be argued that USA has military, economic and diplomatic power at the global level. The same can be said about South Africa regarding its economic and diplomatic power leverage, which it uses to influence the outcomes of events in Africa. Certainly South Africa does not possess the military power and capability to intervene meaningfully outside its territory even in Africa (Habib \& Selinyane, 2004). Our view is that South Africa's neo-liberalization policy is underlined by its desire to acquire soft power within the African continent by drawing on its position as the continent's economic hub.

South Africa may lack superior military power in the global power configuration, but given its economic prowess in Africa, it stands to benefit as a major role player in global trade and commerce, which may enhance its effort towards successful transformation strategy for its reconstruction projects. South Africa pursues global power and influence using economic and diplomatic measures, which it gathers through free trade particularly in Africa, where it plays ahead of other states. Analysts agree that global interactions that pertain to neo-liberal issues (such as civil society, human rights, non-state actors, socio-economic development and global political economy) far outweigh issues of war and/or security. This is the actual direction South African policymakers have positioned the country through free trade and commerce at global level. Our view is that realist theorists are not just the proponents of state drive towards acquisition of military power in the global affairs; the current interest of state in protecting national interest has systematically shifted to a state positioning itself towards advantageous roles in global political economy through trade and commerce.

Thies's (2002) view is that the application of idealism and realism at global and national level has given victory to realists over idealism in international relations debate. Thies believes that idealism became problematic, as states and analysts rejected it based on evidence of its weakness. This could be the reason why South African policymakers clearly choose realism over idealism in their approach to international trade and commerce, which is the brain behind its choice of neo-liberalism in this age of globalization. The truth is that neo-liberal policy has given South Africa a new face in the world economic relations.

3.2. Overview of South Africa and Chinese bilateral trade. China established formal relations with South Africa in 1998 and, since then, the relationship has continued to improve in several directions especially with regard to trade and commerce. Edwards and Jenkins $(2012,2014,2015)$ argue that the increased penetration of manufactured products from China into South African market is said to have lowered South African manufacturing output by 5\% in 2010 than the expected output, while the estimated total loss in employment in manufacturing industry was about $8 \%$ in the year 2010 because of increased Chinese products penetration into South African market. China became a member of World Trade Organization in 2001 and since joining, its trade with South Africa has increased tremendously. South African imports from China rose from less than $\$ 1.1$ billion in 2001 to $\$ 14.2$ billion in 2011, while South Africa's export to China rose from less than $\$ 0.5$ billion in 2001 to $\$ 12.4$ billion in 2011 .

\section{Relationship between textile imports and employment levels}

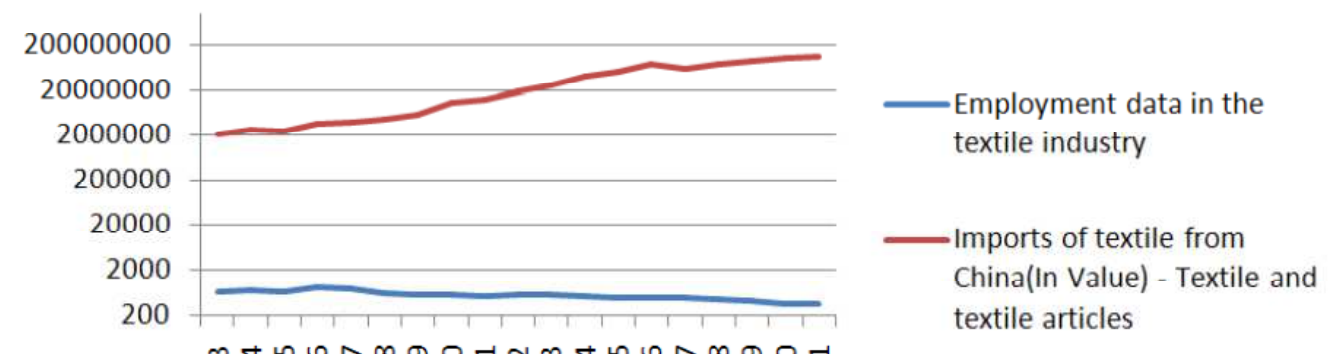

Source: Edoun and Netshiozwi (2015).

Fig. 1. Relationship between textile imports and employment levels 
Edoun and Netshiozwi (2015) examined the impact of Chinese imports into South Africa, especially textile and clothing imports, on employment and concluded that jobs fared negatively in the country (see Fig. 1 above). This means that the penetration of Chinese products into South Africa is taking away jobs from South African manufacturing industries. Essentially, an increase in the value of textile imports from China causes a decline in employment levels in the South African textile industry and in the economy generally.

South Africa and Chinese trade grew from US\$14 million in 1991 to US\$800 million in 1998. By 2002, it had reached US\$2 billion and it grew to USS\$11.2 billion in 2007. With US $\$ 16.3$ billion trade of South Africa and Chinese two way trade in 2009, China has by far become the biggest trade partner of South Africa with total trade between the two countries representing $25 \%$ of Chinese total trade with Africa. Records also show aggressive investment exchange between the two countries going on side by side with trade. South Africa is by far the most advanced country in Africa in manufacturing and services; for example, mining, textiles, electronics, agriculture, communications, transportation and banking, as a result, China holds the view that South Africa is the gateway to African economy (Beeson, Soko and Yong, 2011).

Table 1. Top 10 countries in sub-Saharan Africa by number of investment projects in China

\begin{tabular}{|l|c|c|}
\hline \multicolumn{1}{|c|}{ Country } & Number of projects & $\begin{array}{c}\text { Share of SSA's total projects in China } \\
(\%)\end{array}$ \\
\hline Mauritius & 1,657 & 54.76 \\
\hline Seychelles & 877 & 28.98 \\
\hline South Africa & 201 & 6.64 \\
\hline Nigeria & 67 & 2.21 \\
\hline Liberia & 20 & 0.66 \\
\hline Angola & 17 & 0.56 \\
\hline Zambia & 15 & 0.50 \\
\hline Madagascar & 11 & 0.36 \\
\hline Sudan & 11 & 0.36 \\
\hline Ghana & 10 & 0.33 \\
\hline Namibia & 10 & 0.33 \\
\hline
\end{tabular}

Source: MOFCOM (2012) as quoted in Pigato and Tang (2015).

Interestingly, evidence suggests that while Chinese products penetration into South African market remains higher, its investment growth in South Africa remains slow because of such factors as labor laws, high labour cost and powerful trade unions (Beeson et al 2011). However, the table above (see Table 1) still shows that South Africa is the 3rd investment destination of China in sub-Saharan Africa after Mauritius and Seychelles. Guillaumont and Hua (2015) found that exports of manufactured commodities from China into African countries negatively affected African manufacturing industries. In general terms, the influence of Chinese manufactured products remains a negative influence on Africa's industrial growth.
The trend of impact of Chinese products in African market remains the same even with the most industrialized country in Africa (South Africa). However, we argue that South Africa's realist approach to international trade has cost it so much in its manufacturing sector. Many argue that the manufacturing industry is near deindustrialization in South Africa owing to South Africa's neoliberalization of its downstream economy beginning from the 1990s. In 2014, South Africa recorded a trade deficit of R73bn with China according to the International Relations Minister Maite Nkoana-Mashabane. A critical look at the breakdown of the trade transaction indicates that South African trade exports to China amounted to about R94bn, while imports from China were approximately R167bn for a total trade that amounted to R262bn between South Africa and China in 2014.

From the UN Comtrade (2015) for goods data and UN Comtrade (2014) for trade partners with South Africa, imports from China accounted for $25 \%$ or $\$ 15.4 \mathrm{bn}$ of the total import from the top 10 trade partners of South Africa, while South Africa's export to China accounts for $19 \%$ or $\$ 8.6 \mathrm{bn}$ of the total export to the top 10 trade partners. This trade imbalance between South Africa and China partly explains why manufacturing industry in South Africa is facing a serious deindustrialization problem.

Table 2. Trade partners

\begin{tabular}{|l|c|c|}
\hline \multicolumn{1}{|c|}{ Top 10 export partners } & Export volume $(\$)$ & $\%$ export \\
\hline China & $\$ 8,680,021,942$ & $19 \%$ \\
\hline United States & $\$ 6,420,025,627$ & $14 \%$ \\
\hline Japan & $\$ 4,869,325,871$ & $10 \%$ \\
\hline Botswana & $\$ 4,774,961,315$ & $10 \%$ \\
\hline Namibia & $\$ 4,529,160,727$ & $10 \%$ \\
\hline Germany & $\$ 4,236,185,162$ & $9 \%$ \\
\hline India & $\$ 3,769,815,070$ & $8 \%$ \\
\hline United Kingdom & $\$ 3,458,918,635$ & $7 \%$ \\
\hline Mozambique & $\$ 3,001,627,305$ & $6 \%$ \\
\hline The Netherlands & $\$ 2,995,893,001$ & $6 \%$ \\
\hline Top 10 import partners & Import volume $(\$)$ & $\%$ export \\
\hline China & $\$ 15,449,362,413$ & $25 \%$ \\
\hline Germany & $\$ 10,003,241,740$ & $16 \%$ \\
\hline Saudi Arabia & $\$ 7,129,423,486$ & $12 \%$ \\
\hline United States & $\$ 6,595,504,413$ & $11 \%$ \\
\hline Nigeria & $\$ 5,135,808,001$ & $8 \%$ \\
\hline India & $\$ 4,551,486,012$ & $7 \%$ \\
\hline Japan & $\$ 3,777,363,593$ & $6 \%$ \\
\hline United Kingdom & $\$ 3,271,703,012$ & $5 \%$ \\
\hline Italy & $\$ 2,641,239,165$ & $4 \%$ \\
\hline Thailand & $\$ 2,376,335,344$ & $4 \%$ \\
\hline
\end{tabular}

Source: UN Comtrade (2015) for goods data and UN Comtrade (2014) for trade partners data. 


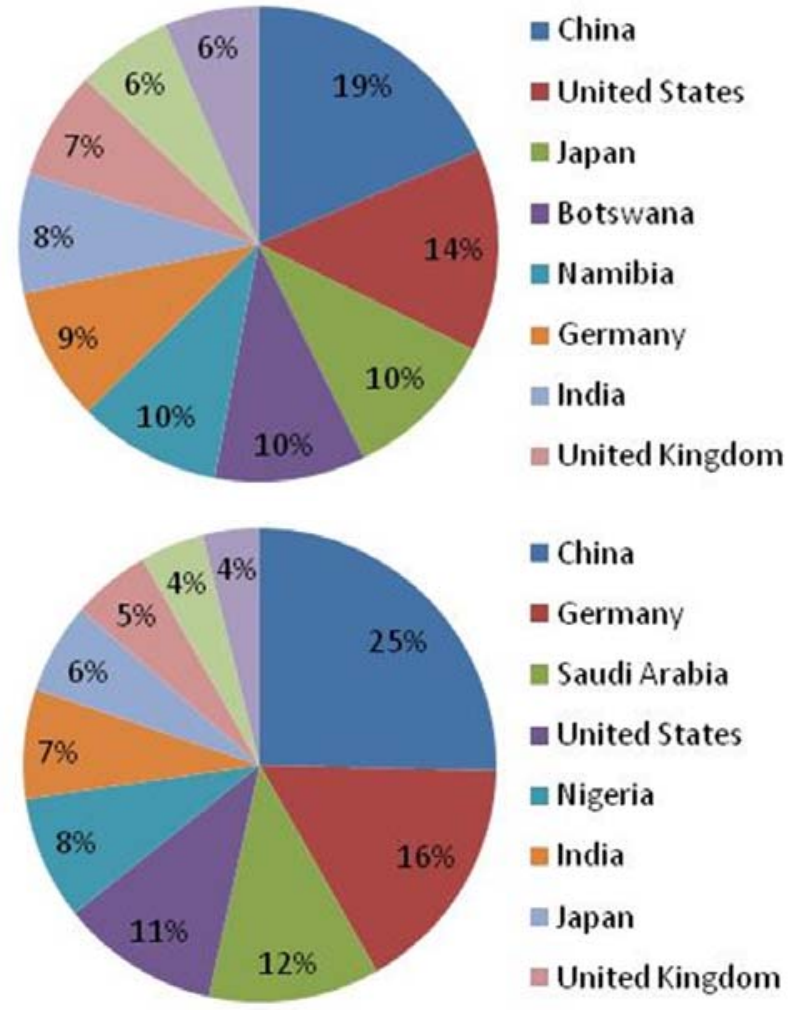

Fig. 2. Percentage distribution

\section{The Socio-economic impact of Chinese import on South African manufacturing sector}

The impact of Chinese exports on South Africa's manufacturing sectors has been a subject of extensive debate in several circles. Basically, research and commentaries have focused on the impact on production, employment, skills acquisition and technology, as well as pricing of locally manufactured goods.

In our opinion, production in South Africa's manufacturing sector remains low since its neo-liberalization in the 1990s. The imports from more competitive manufacturing economies such as China, India and Brazil have gained much access into South African economy and as such, have pushed local manufacturing companies to the background. Arguably, South Africa has continued to lag behind in investment in manufacturing industry since end of apartheid following South African adoption of neo-liberalization since 1990s till date. For example, in 2015, national treasury of South Africa reported that the service sector returned to a reasonable capacity, and mining sector also recovered from long strikes in 2014; however, this improvement in both sectors did not prevent the decline in agricultural and manufacturing sectors of South Africa (National Treasury, 2016).

According to StatsSA (2014), there was decline in growth of manufacturing sector as a result of low production activities in basic iron and steel, non-ferrous metal products, metal products and machinery, petroleum, chemical products, rubber and plastic products, wood products, paper publishing and printing activi- ties. During legal apartheid days, South African manufacturing sector's growth increased from $10 \%$ to near $18 \%$ of aggregate output over the period of 1960 to 1980 , but has declined to about $13 \%$ to $14 \%$ of aggregate production in post-apartheid South Africa (Feddereke, 2014). There has also been a consistent reduction in manufacturing sector employment from $14 \%$ in 1970 s to $11 \%$ in 2012 (Feddereke, 2014).

We also hold the view that Chinese export to South Africa since beginning of 1990s to 2010 has caused drastic reduction in employment opportunities in South Africa's manufacturing sector. The estimated job loss in manufacturing sector between 1992 and 2010 was 145,000 , while manufacturing jobs loss was equivalent to $45 \%$ overall employment loss in South Africa within the same period (Edwards \& Jenkins, 2015). Edwards and Jenkins (2015) further estimated that Chinese exports into South Africa between 1992 and 2010 would negatively impact employment in South Africa's manufacturing sector by over $8.2 \%$. Import of Chinese products into South Africa has also led to creation of lower paid jobs. For example, retail businesses have sprung up in many parts of South Africa with most of them stocking Chinese products. This no doubt has created lower paid jobs, which often are below the minimum wage.

4.1. Skills acquisition and technology. Drawing from the aggregate labor productivity associated with Chinese competition, employment in manufacturing sector has been reduced by 43,000 jobs over the period of 1992 to 2010 , which is equivalent to $7.5 \%$ of the 578,000 jobs lost due to improvements experienced in labor intensive method of production (Edwards \& Jenkins, 2015). Our view is in line with the argument provided by Amiti and Konings (2007) that access to cheaper imported products may likely raise output in manufacturing industry by incorporating learning of new skills and technology of producing new products, varieties of goods, as well as adding quality improvement of products. However, South Africa's neoliberal/realist tendencies have failed to take advantage of new skills and technology of imported manufactured products from China or from elsewhere. Rather than take the opportunity provided by imports from China in skills and technology acquisition, South African manufacturing industry turned the pressure on government to provide the local companies with concessions that will make them competitive in the local market. As important as protectionist policy may be in helping local industries, the onus still rests on South African manufacturing industry to learn newer skills and technology that may make it more competitive locally and internationally. The complaint and need for protectionist policy from infant or declining industries explains lack of innovation in the developing economies like South Africa and this may continue to drive the political economy of the country towards unequal exchange with competitive China. 
4.2. Low pricing of locally manufactured products: In South Africa's market, there is evidence that competition from foreign products has lowered the price of locally made commodities. These price pressures and outright rise in importation of goods, especially in labor intensive industries that developed into home manufacturers of textile and clothing products elicited the imposition of import quotas on imports from China in 2007 and 2008 (Edwards \& Rankin, 2012). At least in the short run, this restriction through quota introduction to Chinese importation saved South Africa from serving as a dumping ground for Chinese products, as well as the control of price inflation in the country. Imports from China, therefore, moderated increases in consumer prices and helped to curtail production cost increases (Edwards \& Rankin, 2012). Overall, China has practiced dumping on South African market (see Nhlabatsi, 2014), but it has largely been limited because of introduction of quota system.

\section{The impact of Chinese export into South Africa on social life of South Africans}

The impact of Chinese export to South Africa has not only been felt in the manufacturing sector, but also on the social life of the average South African. The penetration of Chinese goods into South Africa has led to negative effects on employment, production, lower prices of locally produced goods and finally skills acquisition, but we argue here that the ultimate losers are the citizens. The citizens bear the burden of all the negative results of Chinese import into South Africa. However, in this section, our focus is divided into two categories; therefore, this section discusses how Chinese imports into South Africa have systematically encouraged overspending and exacerbated poverty levels among South Africans.

5.1. Overspending. Overspending means the act of spending on things that cost above the amount budgeted or planned for spending (Hornby, 2003). It has become common among South Africans to engage in the act of spending more than their income could permit or allow them. Nhlabatsi (2014) argues that considering China's cheap and inferior goods, South Africans tend to overspend on them. This is an indication that poverty and low income among large number of South Africans drive the reliance on Chinese goods and products. Essentially, as South African economy continues to tighten especially within the middle income earners, they may have no option other than to continue to rely on Chinese inferior and pirated goods (Nhlabatsi, 2014). Inferior goods are products that the demand slows down as income of consumers rises (see Nicholson \& Snyder, 2008, pp. 143-144, 723). We are of the view that with the poor state of the rand, increase in earnings is unlikely, thus, these inferior goods become attractive despite their lack of durability. After all, inferior and pirated goods are not durable (Nhlabatsi, 2014). Our argument is that this situation creates the possibility that South Africans end up spending far more than their budget.

5.2. Increase in poverty. Poverty means people being in a typical condition, where they may not be able to afford the basic needs of life such as food, clothing, and shelter (Hornby, 2003). Chinese imports into South Africa have created a necessary condition for relative poverty to grow among citizens. This simply means that South Africans citizens do not enjoy certain minimum standards of living that have been determined by the government and international organizations as basic for crossing poverty lines. In many instances, the basic standard of living is attainable by greater number of the population and usually varies from country to country.

Our argument is that it appears that cheap Chinese products in South African market have negatively impacted on South African manufacturing sector leading to lower production, fall in price of locally produced goods, loss of jobs and lack of skills (see Posso, 2013; Ashournia, Munch \& Nguyen, 2014). We also argue that those who lost their jobs and businesses in the manufacturing industry because of importation of Chinese products have become impoverished. The lower paid jobs that Chinese exports to South Africa have created do not make up for the lowered standard of living. Fingers have generally pointed at the new liberal policy of South Africa since the end of apartheid in 1994 as being responsible for the negative outcomes.

\section{Conclusion}

South Africa's neo-liberalization policy started at the end of legal apartheid in the country in 1990s with the intention to open up space for socio-economic development of the country through free trade and inflow and outflow of foreign direct investment. It was part of South Africa's effort to get re-integrated into international political economy. This strategy was also part of the plan to put transformation policy of the country into effect. South Africa's neo-liberalization idea was to follow the step of successful capitalist countries of Europe and Americas, but it was not fully successful, because it opened up so much space for Chinese pirated and inferior goods in South Africa's market.

Chinese exports of manufactured products into South Africa since the beginning of 1990 s have been excessive and have created a situation that South Africa's manufacturing industry is facing deindustrialization. The effect of Chinese exports into South Africa's manufacturing industry include: unemployment, negative pricing of locally produced goods, low productivity, over spending, increase in poverty and shortage of skills. We are of the view that because of the negative impact of Chinese manufactured products, South Africa has been forced into unequal relations with China. The unequal relations between the two countries are caused by some level of structural division of labor. In this instance, South Africa has been subjected into be- 
ing a producer of primary goods, while China remains a producer of manufactured products. International relations theory of realism remains the best theory to explain South Africa's move into the global economy with such a full force of neo-liberalization policy. In the quest for South Africa to seek relevance in the international political economy, it needed economic power that will make things work for its political economy. South Africa's idea is to acquire economic power, but for certain, the success has been partial, because, while South Africa has been able to penetrate global political economy, it has lost its own manufactured product's market to China owning to Chinese role in South Africa's market. South Africa's attempt to regain the manufactured products market through protectionist policy, precisely quota system to Chinese manufactured products, has not been successful because of the limitations placed on South Africa through its membership of international organizations such as WTO and BRICS.

\section{References}

1. Amin, M., Naseer, R. and Ishtiaq, T. (2011). Realism - Dominating Theory in International Relations: An analysis, Berkeley Journal of Social Sciences, vol. 1, No. 7, pp. 1-11.

2. Amiti, M. \& Konings, J. (2007). Trade liberalization, intermediate inputs, and productivity: Evidence from Indonesia, American Economic Review, 97, pp. 1611-1638. doi:10.1257/aer.97.5.1611

3. Andreasson, S. (2010). South Africa and the political economy of postcolonial Africa: emerging markets or increased marginalisation? Draft Paper unpublished, pp. 1-22.

4. Andreasson, S. (2011). Africa's Prospects and South Africa's Leadership Potential in the Emerging Markets Century, Third World Quarterly, Vol. 32, No. 6, pp. 1165-1181.

5. Ashournia, D., Munch, J., Nguyen, D. (2014). The Impact of Chinese Import Penetration on Danish Firms and Work. Discussion Paper No. 8166, Social Science Research Network.

6. Beeson, M., Soko, M. and Yong, W. (2011). The New Resource Politics: Can Australia and South Africa Accommodate China? International Affairs, Vol. 87, No. 6, pp. 1365-1384.

7. Bernard, A.B., Jensen, J.B., and Schott, P.K. (2006). Survival of the Best fit: Exposure to Low-wage Countries and the (uneven) Growth of U.S. Manufacturing Plants, Journal of International Economics, 68, pp. 219-237.

8. Brooks, S.G. and Wohlforth, W.C. (2005). International Relations Theory and the Case against Unilateralism, Vol. 3, No. 3, pp. 509-524.

9. Davies, R. (2012). Parliamentary response from the Minister of Trade and Industry to a request by the official opposition (Democratic Alliance) on the extent of trade between South Africa and its BRICS partners. National Assembly, Cape Town, 29 August 2012.

10. Dey, I. (2005). Qualitative data analysis, London: Routledge, Taylor and Francis Group.

11. Drezner, D.W. (2008). The Realist Tradition in American Public Opinion, Vol. 6, No. 1, pp. 51-70.

12. Edwards, L. \& Jenkins, R. (2015). The Impact of Chinese Import Penetration on the South African Manufacturing Sector, The Journal of Development Studies, 51 (4), pp. 447-463.

13. Edwards, L. \& Rankin, N. (2012). Testing Trade Theory: The Retail Price Impact of Clothing Quotas in South Africa. Paper presented at CSAE Conference, Oxford, March 2012.

14. Edwards, L. and Jenkins, R. (2012). Chinese Competition and the Restructuring of South African Manufacturing DEV research briefing 4 . Economic development - trade.

15. Edwards, L. and Jenkins, R. (2014). The Competitive Effects of China on the South African Manufacturing Sector. Southern African Labour and Development Research Unit (SALDRU).

16. Edwards, L., Naughtin, T. \& Rankin, N. (2011). No Chinese Jackets Required: Quantitative restrictions and quality upgrading in South Africa. Paper presented at International Conference on International Trade and Investment, Mauritius, Dec 2011.

17. Fedderke, W.J. (2014). Exploring Unbalanced Growth in South Africa: Understanding the Sectoral Structure of the South African Economy. South African Reserve Bank Working Paper Series WP/14/07, WP/14/07.

18. Federico, S. (2010). Industry Dynamics and Competition from Low-wage Countries: Evidence on Italy.

19. Fourie, P. (2013). Turning dread into capital: South Africa's AIDS Diplomacy, Fourie Globalization and Health, Vol. 9 , No. 8, pp. 1-13.

20. Freemantle, S. and Stevens, J. (2013). BRIC and Africa - BRICS trade is flourishing and Africa remains a pivot. Standard Bank. February 12, 2013. Available at: https://m.research.standardbank.com/DocumentReader?docId=16715E15D65CF1904D22850B65E04864FC94-1.

21. Guillaumont, J.S, Hua, P. (2015). The Impact of Chinese Competition on Africa's manufacturing. Etudes et Documents, no 21, CERDI. Available at: http://cerdi.org/production/show/id/1721/type_production_id/1.

22. Gumede, W. (2014). The BRICS Alliance: Challenges and Opportunities for South Africa and Africa, Shifting Power Critical perspectives on emerging economies, TNI Working Papers.

23. Habib, A. and Selinyane, N. (2004). South Africa's Foreign Policy and Realistic Vision of an African Century, South Africa's Foreign Policy 1994-2004, Apartheid Past, Renaissance Future in Sidropoulos: The South African Institute of International Affairs Johannesburg, pp. 49-60.

24. Hart, K. and Padayachee, V. (2013), A history of South African capitalism in national and global perspective, Transformation: Critical Perspectives on Southern Africa, Number 81/82, Project Muse, Published by Transformation, DOI: 10.1353/trn.2013.0004, pp. 55-85.

25. Horney, A.S. (2003). Oxford Advanced Learner's Dictionary, Oxford University Press, Great Clarendon Street, Oxford 6DP. 
26. Keaney, B.A. (2006). The Realism of Hans Morgenthau', A thesis submitted in partial fulfillment of the requirements for the degree of Master of Arts Department of Government and International Affairs College of Arts and Sciences University of South Florida, pp. 1-94.

27. Mail and Guardian. (2012). South Africa and China in Awkward Embrace. Mail and Guardian, 19/7. Retrieved August 1, 2012, from http://mg.co.za/article/2012-07-19-south-africa-and-china-in-awkward-embrace.

28. Mearsheimer, J.J. (2002). Realism the Real World and the Academy', in Michael Brecher and Frank P. Harvey, eds., Realism and Institutionalism in International Studies, Ann Arbor: The University of Michigan Press, Pp. 23-33.

29. Mills, G. (2004). Back to the Future? A Review of a Decade of International Relations Thinking. South Africa's Foreign Policy 1994-2004. Apartheid Past, Renaissance Future in Sidiropoulos: The South African Institute of International Affairs Johannesburg, pp. 3-32.

30. Mogalakwe, M. (2006). Research Report. The Use of Documentary Research Methods in Social Research African Sociological Review, 10 (1), pp. 221-230.

31. Ncube, Mthuli, Shimeles, Abebe, Verdier-Chouchane, Audrey. (2012). South Africa's Quest for Inclusive Development, Working Paper Series N 150 African Development Bank, Tunis, Tunisia, pp 1-28.

32. Nhlabatsi, R. (2014). Cheap Chinese imports in Africa: Implications and remedies, Consultancy Africa Intelligence Published 06 Mar 2014: In on Africa IOA.

33. Nicholson, W. and Snyder, C. (2008). Microeconomic Theory, Basic Principles and Extensions. Tenth Edition. Thomson Higher Education, 5191 Natorp Boulevard, Mason, OH 45040, USA.

34. Nitzan, J. and Bichler, S. (2004). Montreal and Jerusalem, New Imperialism or New Capitalism? Available at: http://bnarchives.yorku.ca/124/01/041214NB_NewImperialismNewCapitalism(Ver2).pdf. Accessed on 26/06/2014, pp. 1-70.

35. Onyekwena, C., Taiwo, O., Uneze, E. (2014). South Africa in BRICS: A Bilateral Trade Analysis, Occasional Paper, No. 181, Economic Diplomacy Programme, SAIIA.

36. Payne, G. and Payne, J. (2004). Key Concepts in Social Research, London: Sage Publications.

37. Pigato, M. and Tang, W. (2015). China and Africa: Expanding Economic Ties in an Evolving Global Context. Investing in African Forum, Executive Summary.

38. Posso, A. (2013). Enter the Dragon: Have Imports from China Hurt Wages in Manufacturing, Asian Economic Journal, 27 (3), pp. 307-321.

39. Rodrik, D. (2008). Understanding South Africa's Economic Puzzles, The Economics of Transition, 16, pp. $769-797$.

40. Rose, G. (1998). Neoclassical Realism and Theories of Foreign Policy, World Politics, Vol. 51, pp. 144-172.

41. Sidiropoulos, E. and Hughes, T. (2004). Between Democratic Governance and Sovereignty: Challenge of South Africa's Africa Policy, South Africa's Foreign Policy 1994-2004, Apartheid Past, Renaissance Future in Sidiropoulos: The South African Institute of International Affairs Johannesburg, pp. 61-84.

42. Statistics South Africa. (2014). Gross domestic product Annual estimates 2004 - 2013 Regional estimates 2004 - 2013 Third quarter 2014. In: AFRICA, S. S. (ed.). STAT SA.

43. Thies, C.G. (2002). Progress, History and Identity in International Relations Theory: The Case of the Idealist-Realist Debate', European Journal of International Relations, Vol. 8, No. 2, pp. 147-185.

44. Treasury, N. (2015). Budget Review. In: Treasury, N. (ed.). National Treasury Republic of South Africa. The document is also available on the internet at: www.treasury.gov.za.

45. Umezurike, S.A. (2015). South Africa's Economic Policy towards Africa: Renaissance or Neo-imperialism? Unpublished Thesis, University of Zululand, KwaDlangezwa, South Africa. 